\title{
Antibacterial Susceptibility Pattern of Pathogenic Bacteria Isolates from Vegetable Salad Sold in Restaurants in Zaria, Nigeria
}

\author{
Gbonjubola O. Adeshina*, Samuel D. Jibo, Victor E. Agu \\ Department of Pharmaceutics and Pharmaceutical Microbiology, Ahmadu Bello University, Zaria, 234-, Nigeria
}

\begin{abstract}
Microbiological analysis of 25 vegetable salad samples collected from five locations in Zaria, Nigeria was analysed using standard microbiological methods. Antibiotic susceptibility pattern of the isolates was determined using Kirby-Bauer CLSI modified disc agar diffusion technique (DAD). Antibacterial susceptibility of the isolates to aqueous and ethanol extracts of dry ginger; ethanol extract of fresh ginger (Zingiber officinale) was also investigated using agar diffusion and broth dilution methods. The bacterial load of the salad samples ranged between $6.0 \times 10^{4}$ to $2.0 \times 10^{6} \mathrm{cfu} / \mathrm{ml}$. The predominant bacteria isolated from the samples were Staphylococcus aureus, Salmonella spp, Escherichia coli and Pseudomonas aeruginosa. All the bacteria isolates were found to be sensitive to Ofloxacin while Amoxycilin was found to be the least effective as all the bacteria isolates were resistant to it except a strain of Escherichia coli. Some of the strains of these isolates showed multiple antibiotic resistance to the antibiotics used. The aqueous and ethanol extracts of ginger showed moderate antibacterial activity against the isolates with diameter of zones of inhibition ranging from 13.0 to $28.5 \mathrm{~mm}$. The Minimum Inhibitory Concentration (M.I.C.) and Minimum Bactericidal Concentration (M.B.C) values observed from the extracts against the organisms were moderately high. This study has shown that some vegetable salads are heavily contaminated with potential pathogenic and antibiotic resistant bacteria species; ginger can be an alternative remedy to inhibit pathogenic bacteria isolates from vegetable salad.
\end{abstract}

Keywords Vegetable Salad, Multiple Antibiotic Resistance, Pathogens, Ginger

\section{Introduction}

Vegetable salad is a mixture of fresh vegetables and cream milk that provides a rich source of minerals and dietary fibre of low fat and calories to the consumer (Udo et al., 2009). The increasing availability of prepared vegetable salads reflects consumers demand for fresh, healthy, convenient and additives free foods that should be safe and nutritious. Currently going on is the advocacy for consumption of vegetables and many people are turning to become vegetarians.

However, questions have been raised about the safety and microbiological quality of these food produce (Abdou Raouf and Ammar, 2006). Health risks are associated with initial contamination and subsequent contamination by the workers during handling, while microbial proliferation occurs during display. Salads are usually consumed without any pre-heat treatment and therefore the possibility of food poisoning exists (Buck and Walcott, 2003). In developing countries,

* Corresponding author:

dotunkele@yahoo.com (Gbonjubola O. Adeshina)

Published online at http://journal.sapub.org/microbiolofy

Copyright (C) 2012 Scientific \& Academic Publishing. All Rights Reserved there are serious concerns about the sanitation of the ready-to-eat salads, as portable water is seldom available at preparation venues and fast food stands. In most places, dishes and utensils are often washed with single change of water in the same bowl all day long.

Most pathogens in salad do not cause product spoilage, even at relatively high population. In the absence of spoilages signs, salads are consumed because they are perceived as safe. Several studies have associated outbreak of food poisoning with consumption of raw vegetable salads (Larry, 1995; Portnoy and Geopfert, 1996).

Prevalence and growth of pathogens analysed from one hundred and twenty (120) samples of different raw salad vegetables, pathogens isolated were: Staphylococcus aureus, Escherichia coli, Enterobacter spp, Klebsiella spp, Salmonella typhi, Serratia spp, Providencia spp and Pseudomonas aeruginosa (Viswanathan and Kam, 2001). A World Health Organization reported that Listeria monocytogenes was prevalent in pre-packaged salads and salad vegetables in Canada, Germany, Spain and Northern Ireland. Egypt had prevalence of Salmonella spp. (Buck et al., 2003). A high number of bacteria, including Pseudomonas spp. and Erwinia carotovora were detected in two salad samples (Whong et al., 1987). 
Ginger is the underground stem or rhizome of the plant Zingiber officinale. It belongs to Zingiberaceae. Ginger has been used as a medicine in Asian, Indian, and Arabic herbal traditions since ancient times. In China, for example, ginger has been used to help digestion and treat stomach upset, diarrhoea, and nausea for more than 2,000 years. Ginger has also been used to help treat arthritis, colic, diarrhoea, and heart conditions. It also has been used to help treat the common cold, flu-like symptoms, headaches, and painful menstrual periods (Steven and Ehrlich, 2010).

In addition to being used as a medicine, ginger is used throughout the world as an important cooking spice. Ginger is native to Asia where it has been used as a cooking spice for at least 4,400 years (Steven and Ehrlich, 2010).

In recent years, salad has become a very popular component of menu served in birthdays and wedding parties; they are also sold in fast food centres in most major cities in Nigeria. Media reports of unverified rampant cases of gastroenteritis following consumption of meals served with fresh vegetable salads have become serious public health concern. Therefore, this work tends to provide information on the microbiological quality of some ready-to-eat vegetable salads; identify the pathogenic bacteria contaminants; and test the susceptibility of the pathogens to some commonly prescribed antibiotics and extracts of ginger.

\section{Materials and Methods}

\subsection{Sample Collection of Vegetable Salad}

A total of twenty-five (25) salad samples were collected with five samples from three restaurants on Ahmadu Bello University, Zaria campus and two off campus. The samples were worked on immediately after collection.

\subsection{Collection/Identification of Plant Material}

Dry rhizome of the plant (Zingiber Officinale) was collected at Samaru market, Samaru- Zaria, Nigeria, in July 2010. It was identified at the herbarium of the Department of Biological Science, Ahmadu Bello University Zaria and a voucher with specimen number 2261 was kept for future reference.

\subsection{Extraction of the Plant Material}

The dry rhizomes were grinded using mortar and pestle. Using the Soxhlet extractor, 400 gm of the grinded rhizomes was extracted with $450 \mathrm{ml}$ of water at room temperature until all the extractable components were exhausted. The extract was concentrated, dried, weighed and kept in a dessicator until needed. The same procedure was carried out for the ethanol extract.

\subsection{Isolation, Identification and Characterization of Organism}

One gram (1.0 g) of thoroughly mixed salad sample was aseptically added to $18 \mathrm{ml}$ of sterile nutrient broth and incubated overnight at $37^{\circ} \mathrm{C}$ for 24 hours. The mixture of nutrient broth and salad sample was sub-cultured on sterile nutrient agar plate under aseptic condition and incubated at $37^{\circ} \mathrm{C}$ for $18-24$ hours. All the experiments were carried out three times. The total bacterial load was counted in the agar plates and the average viable count was recorded. Colonies were selected using their morphological characteristics (size, pigmentation, elevation and consistency). Gram staining methods and further biochemical tests were carried out to identify the organisms that were isolated from the salad samples.

\subsection{Antibiotic Susceptibility Pattern of the Pathogen Isolated from Salad Samples}

The susceptibility pattern of the pathogenic isolates from salad samples to $25 \mu \mathrm{g}$ amoxicillin, $30 \mu \mathrm{g}$ Augmentin, $25 \mu \mathrm{g}$ Cotrimoxazole, $10 \mu \mathrm{g}$ Gentamicin, $30 \mu \mathrm{g}$ Nalidixic acid, 300 $\mu \mathrm{g}$ Nitrofuratoin, $30 \mu \mathrm{g}$ Ofloxacin and $30 \mu \mathrm{g}$ tetracycline (Abtek) were determined using Kirby-Bauer-CLSI modified disc agar diffusion technique (DAD) (Cheesbrough, 2006). The 24-hour broth culture of the isolates was diluted to McFarland standard $\left(10^{5}-10^{6} \mathrm{cfu} / \mathrm{ml}\right)$. One millilitre $(1.0 \mathrm{ml})$ of standardised culture of each isolate was used to flood the surface of Mueller Hinton agar (MHA) plates and excess drained off and dried while the Petri dish lid was in place. The standard antibiotic discs were then aseptically placed at reasonable equidistance on the inoculated MHA plates and allowed to stand for 30 mins to allow the antibiotics to diffuse in the agar medium. The plates (prepared in duplicates for each isolate) were then incubated at $37^{\circ} \mathrm{C}$ for $18 \mathrm{~h}$ (Ehinmidu, 2003). The diameter of the zones of inhibition produced by each antibiotic disc was measured and recorded. The average mean diameter zones of inhibition were taken.

\subsection{Antibacterial Susceptibility Testing of the Resistant Pathogens to Ginger Extracts}

The washed overnight broth cultures of the resistant pathogenic bacteria isolates were diluted appropriately using sterile normal saline to $0.5 \mathrm{McF}$ arland scales (0.5 McFarland is about $\left.10^{6} \mathrm{cfu} / \mathrm{ml}\right)$. The molten sterile nutrient agar $(20 \mathrm{ml})$ was poured into sterile Petri dish and allowed to set. The sterile nutrient agar plate was flooded with $1.0 \mathrm{ml}$ of the standardized test organism and the excess was drained off and dried at $30^{\circ} \mathrm{C}$ for $1 \mathrm{hr}$. A sterile cork borer (No. 4) was used to bore equidistant cups into the agar plate. One drop of the molten agar was used to seal the bottom of the bored hole, so that the extract will not sip beneath the agar. $0.1 \mathrm{ml}$ of the different concentrations $(6.25 \mathrm{mg} / \mathrm{ml}-100 \mathrm{mg} / \mathrm{ml})$ of the extract was added to fill the bored holes. Control plates were prepared. One hour pre-diffusion time was allowed, after which the plates were incubated at $37^{\circ} \mathrm{C}$ for $18 \mathrm{~h}$. The zones of inhibition were then measured in millimetre. The above method was carried out in triplicates and the mean of the triplicate results was taken. 


\subsection{Minimum Inhibitory Concentration (M.I.C.) and Minimum Bactericidal Concentration (M. B. C.) of Ginger Extracts}

Minimum Inhibitory Concentration (M.I.C.) and Minimum Bactericidal Concentration (M. B. C.) of ginger extracts were carried out using broth dilution and agar dilution methods. Eight tubes of $2.5 \mathrm{ml}$ nutrient broth were arranged in rows. The first tube contained double strength broth. To the first was added $2.5 \mathrm{ml}$ of the extract and thoroughly but gently mixed, $2.5 \mathrm{ml}$ of the mixture was withdrawn and to the second tube and mixed properly, this dilution was continued serially to the last tube, after mixing, $2.5 \mathrm{ml}$ was withdrawn from the last tube and discarded. Two drops of standardised inoculum was added to each tube. Three controls were set up to show the sterility of the media, the extract and to ascertain the growth promoting property of the media. The tubes were incubated at $37^{\circ} \mathrm{C}$ for 18 hours. The lowest concentration of the extract in the test tubes that showed no growth was considered as the M. I. C. of the extract against the test bacteria.

After incubation a loopful from the tubes containing the least concentration of the extract which prevent growth was streaked on sterile nutrient agar plates containing inactivating agents $3 \% \mathrm{v} / \mathrm{v}$ Tween 80 incubated at $37^{\circ} \mathrm{C}$ for 24 hours. The least concentration of the extract in the test agar plates that showed no growth was considered as the M. B. C. of the extract against the test bacteria (Onaolapo et al., 1993).

\section{Results}

Table 1. Bacterial Viable Count from the Vegetable Salad Samples

\begin{tabular}{|c|c|c|c|c|c|c|c|c|}
\hline $\begin{array}{l}\text { Sample } \\
\text { location }\end{array}$ & Sample & $\begin{array}{l}\text { Bacterial viable count } \\
(\mathrm{cfu} / \mathrm{gm})\end{array}$ & $\begin{array}{l}\text { Bacillus } \\
\quad s p .\end{array}$ & Staph. aureus & CoNS & Ps. aeruginosa & E. coli & Salmonella $s p$. \\
\hline A & $\begin{array}{l}\mathrm{A}_{1} \\
\mathrm{~A}_{2} \\
\mathrm{~A}_{3} \\
\mathrm{~A}_{4} \\
\mathrm{~A}_{5}\end{array}$ & $\begin{array}{l}8.3 \times 10^{5} \\
1.1 \times 10^{6} \\
2.1 \times 10^{5} \\
1.0 \times 10^{5} \\
2.1 \times 10^{5}\end{array}$ & $\begin{array}{l}+ \\
+ \\
+ \\
+ \\
-\end{array}$ & $\begin{array}{l}- \\
+ \\
- \\
- \\
-\end{array}$ & $\begin{array}{l}- \\
- \\
- \\
- \\
-\end{array}$ & $\begin{array}{l}- \\
- \\
- \\
- \\
-\end{array}$ & $\begin{array}{l}- \\
- \\
- \\
- \\
-\end{array}$ & $\begin{array}{l}- \\
- \\
- \\
- \\
+\end{array}$ \\
\hline B & $\begin{array}{l}\mathrm{B}_{1} \\
\mathrm{~B}_{2} \\
\mathrm{~B}_{3} \\
\mathrm{~B}_{4} \\
\mathrm{~B}_{5} \\
\end{array}$ & $\begin{array}{l}1.3 \times 10^{5} \\
9.5 \times 10^{5} \\
2.2 \times 10^{5} \\
3.0 \times 10^{5} \\
2.1 \times 10^{5}\end{array}$ & $\begin{array}{l}- \\
- \\
+ \\
+ \\
+\end{array}$ & $\begin{array}{l}+ \\
- \\
- \\
- \\
-\end{array}$ & $\begin{array}{l}- \\
- \\
- \\
- \\
-\end{array}$ & $\begin{array}{l}+ \\
+ \\
- \\
- \\
-\end{array}$ & $\begin{array}{l}- \\
- \\
- \\
- \\
-\end{array}$ & $\begin{array}{l}+ \\
- \\
- \\
- \\
-\end{array}$ \\
\hline $\mathrm{C}$ & $\begin{array}{l}\mathrm{C}_{1} \\
\mathrm{C}_{2} \\
\mathrm{C}_{3} \\
\mathrm{C}_{4} \\
\mathrm{C}_{5}\end{array}$ & $\begin{array}{l}7.0 \times 10^{5} \\
2.0 \times 10^{6} \\
6.0 \times 10^{5} \\
4.1 \times 10^{5} \\
1.0 \times 10^{5}\end{array}$ & $\begin{array}{l}++ \\
+ \\
- \\
- \\
+\end{array}$ & $\begin{array}{l}+ \\
- \\
- \\
- \\
-\end{array}$ & $\begin{array}{l}- \\
- \\
- \\
+ \\
-\end{array}$ & $\begin{array}{l}- \\
- \\
- \\
- \\
-\end{array}$ & $\begin{array}{l}- \\
- \\
+ \\
- \\
-\end{array}$ & $\begin{array}{l}- \\
- \\
- \\
- \\
-\end{array}$ \\
\hline D & $\begin{array}{l}D_{1} \\
D_{2} \\
D_{3} \\
D_{4} \\
D_{5}\end{array}$ & $\begin{array}{l}9.4 \times 10^{5} \\
1.6 \times 10^{5} \\
2.1 \times 10^{5} \\
3.9 \times 10^{5} \\
6.0 \times 10^{5}\end{array}$ & $\begin{array}{l}- \\
- \\
+ \\
+ \\
-\end{array}$ & $\begin{array}{l}- \\
- \\
- \\
- \\
-\end{array}$ & $\begin{array}{l}+ \\
- \\
+ \\
- \\
-\end{array}$ & $\begin{array}{l}- \\
- \\
- \\
- \\
-\end{array}$ & $\begin{array}{l} \\
+ \\
- \\
+ \\
+\end{array}$ & $\begin{array}{l}- \\
- \\
- \\
- \\
+\end{array}$ \\
\hline $\mathrm{E}$ & $\begin{array}{l}E_{1} \\
E_{2} \\
E_{3} \\
E_{4} \\
E_{5}\end{array}$ & $\begin{array}{l}1.1 \times 10^{6} \\
6.1 \times 10^{5} \\
2.3 \times 10^{5} \\
4.2 \times 10^{5} \\
6.6 \times 10^{5}\end{array}$ & $\begin{array}{l}+ \\
- \\
- \\
+ \\
+\end{array}$ & $\begin{array}{l}- \\
- \\
- \\
- \\
-\end{array}$ & $\begin{array}{l}- \\
+ \\
+ \\
- \\
-\end{array}$ & $\begin{array}{l}- \\
- \\
- \\
- \\
-\end{array}$ & $\begin{array}{l}- \\
- \\
- \\
- \\
-\end{array}$ & $\begin{array}{l}- \\
- \\
- \\
-\end{array}$ \\
\hline
\end{tabular}

Key: CoNS $=$ Coagulase-negative staphylococcus, $+=$ present, $-=$ absent

The bacterial load of the salad samples was high and varied between the different locations. The bacterial load ranged between $6.0 \times 10^{4} \mathrm{cfu} / \mathrm{g}$ to $2.0 \times 10^{6} \mathrm{cfu} / \mathrm{g}$ (Table 1).

A total of 32 bacteria species were isolated from the salad samples, $12(37.5 \%)$ were pathogens. Three of the total pathogenic bacteria isolated were Staph. aureus $(25.0 \%)$, three Salmonella spp. (25.0\%), four E. coli (33.3\%) and two Ps. aeruginosa (16.\%) (Table 2).

The mean diameter zones of inhibition showed by the used antibiotics against the bacteria isolates ranged between 0.0 $\mathrm{mm}-38.0 \mathrm{~mm}$. The highest zone of inhibition of $38 \mathrm{~mm}$ was produced by Ofloxacin against Salmonella $s p$. while the lowest zone of inhibition of $0.0 \mathrm{~mm}$ was produced by Nalidixic acid and Nitrofurantoin against Staph. sp. and $E$. coli respectively (Table 2 ).

Using the Clinical Laboratory Standard Institute (2008) antibiotics zones of inhibition break point for Staphylococcus aureus, Ps. aeruginosa, E. coli and Salmonella sp. the above results in Table 2, was interpreted as sensitive, intermediate and resistant (Table 3). All the test isolates (100\%) were resistant to Ofloxacin (Tables 3 - 4).

The Multiple Antibiotic Resistance (MAR) index show that Salmonella isolates had the greatest number of multiple antibiotic resistance (Table 5).

Tables 6 and 7 show the antibacterial activity of the aqueous and ethanol extracts of dry ginger and ethanol extract of fresh ginger. Pseudomonas aeruginosa was observed to be resistant to the ginger extracts while $E$. coli was the most susceptible to the ethanol extract of the dry ginger. 
Table 2. Antibiotic Susceptibility Pattern of the Bacteria Isolates from Vegetable Salad Samples

\begin{tabular}{|c|c|c|c|c|c|c|c|c|}
\hline \multirow{2}{*}{$\begin{array}{c}\text { Pathogenic Iso- } \\
\text { lates }\end{array}$} & \multicolumn{9}{|c|}{ Zone of Inhibition (mm) } \\
\cline { 2 - 10 } & AMX & AUG & COT & GTN & NAL & NFT & OFL & TET \\
\hline$S a \mathrm{~A}_{2}$ & 9.0 & 8.0 & 9.0 & 15.5 & 0.0 & 15.0 & 24.0 & 19.0 \\
$S a \mathrm{~B}_{1}$ & 14.0 & 20.0 & 23.0 & 17.0 & 9.0 & 25.5 & 35.5 & 20.5 \\
$S a \mathrm{C}_{1}$ & 9.0 & 15.0 & 20.0 & 10.5 & 10.0 & 21.0 & 27.0 & 14.5 \\
\hline$P s \mathrm{~B}_{1}$ & 8.0 & 8.5 & 23.5 & 14.5 & 22.5 & 10.5 & 35.5 & 11.0 \\
$P s \mathrm{~B}_{2}$ & 8.5 & 8.0 & 19.0 & 13.5 & 20.0 & 9.0 & 30.0 & 9.5 \\
\hline$E c \mathrm{C}_{3}$ & 8.5 & 15.0 & 28.0 & 14.0 & 26.0 & 0.0 & 35.0 & 21.0 \\
$E c \mathrm{D}_{2}$ & 8.0 & 14.0 & 17.5 & 13.5 & 20.0 & 8.0 & 28.0 & 22.0 \\
$E c \mathrm{D}_{4}$ & 22.0 & 23.5 & 19.0 & 16.5 & 23.0 & 15.0 & 29.0 & 22.5 \\
$E c \mathrm{D}_{5}$ & 8.0 & 14.4 & 25.0 & 12.5 & 24.0 & 8.0 & 33.0 & 21.5 \\
\hline$S m \mathrm{~A}_{5}$ & 10.0 & 10.0 & 11.5 & 11.0 & 8.0 & 9.0 & 34.0 & 20.5 \\
$S m \mathrm{~B}_{1}$ & 9.0 & 10.0 & 10.0 & 12.5 & 9.0 & 11.0 & 32.5 & 8.0 \\
$S m \mathrm{D}_{5}$ & 8.0 & 20.0 & 26.5 & 27.0 & 31.0 & 26.0 & 38.0 & 16.0 \\
\hline
\end{tabular}

Key: $\mathrm{Sa}=$ Staphylococcus aureus, $\mathrm{Ps}=$ Pseudomonas aeruginosa, $\mathrm{Ec}=$ E. coli, $\mathrm{Sm}=$ Salmonella $\mathrm{sp} ., \mathrm{AMX}=25 \mu \mathrm{g}$ Amoxycilin, $\mathrm{AUG}=30 \mu \mathrm{g}$ Augmentin, $\mathrm{COT}=25$ $\mu \mathrm{g}$ Cotrimoxazole, GTN $=10 \mu \mathrm{g}$ Gentamicin, NAL $=30 \mu \mathrm{g}$ Nalidixic acid, NFT $=300 \mu \mathrm{g}$ Nitrofurantoin, OFL $=30 \mu \mathrm{g}$ Ofloxacin, TET $=30 \mu \mathrm{g}$ Tetracycline.

Table 3. Antibiotic Susceptibility Profile

\begin{tabular}{|c|c|c|c|c|c|c|c|c|c|c|c|c|}
\hline \multirow{2}{*}{ Antibiotics } & \multicolumn{11}{|c|}{ Bacteria isolates } & \multirow[b]{2}{*}{$\mathrm{SmD}_{5}$} \\
\hline & $\mathrm{SaA}_{2}$ & $S a \mathrm{~B}_{1}$ & $\mathrm{SaC} \mathrm{C}_{1}$ & $P_{s} \mathrm{~B}_{1}$ & $P_{s} \mathrm{~B}_{2}$ & $\mathrm{EcC}_{3}$ & $E c \mathrm{D}_{2}$ & $E_{c} \mathrm{D}_{4}$ & $E c \mathrm{D}_{5}$ & $\mathrm{SmA}_{5}$ & $S m \mathrm{~B}_{1}$ & \\
\hline AMX & $\mathrm{R}$ & $\mathrm{R}$ & $\mathrm{R}$ & $\mathrm{R}$ & $\mathrm{R}$ & $\mathrm{R}$ & $\mathrm{R}$ & $\mathrm{S}$ & $\mathrm{R}$ & $\mathrm{R}$ & $\mathrm{R}$ & $\mathrm{R}$ \\
\hline AUG & $\mathrm{R}$ & S & $\mathrm{R}$ & $\mathrm{R}$ & $\mathrm{R}$ & $\mathrm{R}$ & $\mathrm{R}$ & $\mathrm{S}$ & $\mathrm{R}$ & $\mathrm{R}$ & $\mathrm{R}$ & $\mathrm{S}$ \\
\hline COT & $\mathrm{R}$ & $\mathrm{S}$ & $\mathrm{S}$ & I & I & $\mathrm{S}$ & $\mathrm{R}$ & $\mathrm{S}$ & $\mathrm{S}$ & I & $\mathrm{R}$ & $\mathrm{S}$ \\
\hline GTN & $\mathrm{S}$ & $\mathrm{S}$ & $\mathrm{R}$ & $\mathrm{S}$ & $\mathrm{S}$ & $\mathrm{S}$ & $\mathrm{R}$ & $\mathrm{S}$ & $\mathrm{R}$ & $\mathrm{R}$ & I & $\mathrm{S}$ \\
\hline NAL & $\mathrm{R}$ & $\mathrm{R}$ & $\mathrm{R}$ & $\mathrm{S}$ & $\mathrm{S}$ & $\mathrm{S}$ & $\mathrm{S}$ & $\mathrm{S}$ & $\mathrm{S}$ & $\mathrm{R}$ & $\mathrm{R}$ & $\mathrm{S}$ \\
\hline NFT & I & $\mathrm{S}$ & $\mathrm{S}$ & $\mathrm{R}$ & $\mathrm{R}$ & $\mathrm{R}$ & $\mathrm{R}$ & I & $\mathrm{R}$ & $\mathrm{R}$ & $\mathrm{R}$ & $\mathrm{S}$ \\
\hline OFL & $\mathrm{S}$ & $\mathrm{S}$ & $\mathrm{S}$ & $\mathrm{S}$ & $\mathrm{S}$ & $\mathrm{S}$ & $\mathrm{S}$ & $\mathrm{S}$ & $\mathrm{S}$ & $\mathrm{S}$ & $\mathrm{S}$ & $\mathrm{S}$ \\
\hline TET & $\mathrm{S}$ & $\mathrm{S}$ & I & $\mathrm{R}$ & $\mathrm{R}$ & $\mathrm{S}$ & $\mathrm{S}$ & $\mathrm{S}$ & $\mathrm{S}$ & $\mathrm{S}$ & $\mathrm{R}$ & $\mathrm{S}$ \\
\hline
\end{tabular}

Key: $\mathrm{R}=$ Resistance, $\mathrm{S}=$ Sensitive, $\mathrm{I}=$ intermediate

Table 4. Percentage Sensitivity Profile of Bacteria Isolates

\begin{tabular}{|c|c|c|c|c|c|c|c|c|c|c|c|c|}
\hline \multirow[b]{2}{*}{ Antibiotics } & \multicolumn{12}{|c|}{ Sensitivity profile $(\%)$} \\
\hline & \multicolumn{3}{|c|}{$\begin{array}{c}\text { Staph. aureus } \\
\mathrm{n}=3\end{array}$} & \multicolumn{3}{|c|}{$\begin{array}{c}\text { Ps. aeruginosa } \\
\mathrm{n}=2\end{array}$} & \multicolumn{3}{|c|}{$\begin{array}{c}\text { E. coli } \\
\mathrm{n}=4\end{array}$} & \multicolumn{3}{|c|}{$\begin{array}{l}\text { Salmonella sp. } \\
\mathrm{n}=3\end{array}$} \\
\hline AMX & 0.0 & 0.0 & 100 & 0.0 & 0.0 & 100 & 25.0 & 0.0 & 75.0 & 0.0 & 0.0 & 100 \\
\hline AUG & 33.3 & 0.0 & 66.7 & 0.0 & 0.0 & 100 & 25.0 & 0.0 & 75.0 & 33.3 & 0.0 & 66.7 \\
\hline $\mathrm{COT}$ & 66.7 & 0.0 & 33.3 & 0.0 & 100 & 0.0 & 75.0 & 0.0 & 25.0 & 33.3 & 0.0 & 66.7 \\
\hline NAL & 0.0 & 0.0 & 100 & 100 & 0.0 & 0.0 & 100 & 0.0 & 0.0 & 33.3 & 0.0 & 66.7 \\
\hline NFT & 66.7 & 33.3 & 0.0 & 0.0 & 0.0 & 100 & 0.0 & 25.0 & 75.0 & 33.3 & 0.0 & 66.7 \\
\hline OFL & 100 & 0.0 & 0.0 & 100 & 0.0 & 0.0 & 100 & 0.0 & 0.0 & 100 & 0.0 & 0.0 \\
\hline TET & 66.7 & 0.0 & 33.3 & 0.0 & 0.0 & 100 & 100 & 0.0 & 0.0 & 33.3 & 0.0 & 66.7 \\
\hline
\end{tabular}

Table 5. Multiple Antibiotics Resistance (MAR) Indices of Pathogenic Bacteria Isolates

\begin{tabular}{|c|c|c|c|c|}
\hline \multirow{2}{*}{ MAR index } & \multicolumn{4}{|c|}{ Frequency of MAR index (\%) } \\
\hline & $\begin{array}{c}\text { Staph. aureus } \\
\mathrm{n}=3\end{array}$ & $\begin{array}{c}\text { Ps. aeruginosa } \\
\mathrm{n}=2\end{array}$ & $\begin{array}{c}\text { E. coli } \\
\mathrm{n}=4\end{array}$ & $\begin{array}{c}\text { Salmonella sp. } \\
\mathrm{n}=3\end{array}$ \\
\hline 0.0 & 0 & 0 & $1(25)$ & 0 \\
\hline 0.1 & 0 & 0 & 0 & $1(33.3)$ \\
\hline 0.2 & 0 & 0 & 0 & 0 \\
\hline 0.3 & $1(33.3)$ & 0 & 0 & 0 \\
\hline 0.5 & $2(66.7)$ & $2(100)$ & $1(25)$ & 0 \\
\hline 0.6 & 0 & 0 & $1(25)$ & $1(33.3)$ \\
\hline 0.7 & 0 & 0 & 0 & 0 \\
\hline 0.8 & 0 & 0 & 0 & $1(33.3)$ \\
\hline 0.9 & 0 & 0 & 0 & 0 \\
\hline 1.0 & 0 & 0 & 0 & 0 \\
\hline
\end{tabular}

Key: $\mathrm{n}=$ number of isolates 
Table 6. Anti-bacterial Susceptibility of the Resistant Bacteria Isolates to the Aqueous and Ethanol Extracts of Dry Ginger and Ethanol Extract of Fresh Ginger

\begin{tabular}{|c|c|c|c|c|c|c|c|c|c|c|c|c|c|c|c|}
\hline \multirow{3}{*}{$\begin{array}{c}\text { Test } \\
\text { Bacte- } \\
\text { ria }\end{array}$} & \multicolumn{15}{|c|}{ Zones of Inhibition (mm) } \\
\hline & \multicolumn{3}{|c|}{$100 \mathrm{mg} / \mathrm{ml}$} & \multicolumn{3}{|c|}{$50 \mathrm{mg} / \mathrm{ml}$} & \multicolumn{3}{|c|}{$25 \mathrm{mg} / \mathrm{ml}$} & \multicolumn{3}{|c|}{$12.5 \mathrm{mg} / \mathrm{ml}$} & \multicolumn{3}{|c|}{$6.25 \mathrm{mg} / \mathrm{ml}$} \\
\hline & DAE & DEE & FEE & DAE & DEE & FEE & DAE & DEE & FEE & DAE & $\mathrm{DEE}$ & FEE & DAE & DEE & FEE \\
\hline E. coli & $\begin{array}{r}20.5 \\
\pm 1.5 \\
\end{array}$ & $\begin{array}{c}28.5 \pm \\
0.5 \\
\end{array}$ & $\begin{array}{c}24.0 \pm \\
0.0 \\
\end{array}$ & $\begin{array}{c}18.0 \\
\pm 0.0 \\
\end{array}$ & $\begin{array}{r}19.5 \\
\pm 0.5 \\
\end{array}$ & $\begin{array}{r}16.0 \\
\pm 0.0 \\
\end{array}$ & $\begin{array}{l}13.0 \\
\pm 0.0 \\
\end{array}$ & $\begin{array}{r}15.0 \\
\pm 2.1 \\
\end{array}$ & $\begin{array}{r}16.0 \\
\pm 0.0 \\
\end{array}$ & NA & NA & NA & NA & NA & NA \\
\hline $\begin{array}{c}. \\
\text { typhi }\end{array}$ & $\begin{array}{l}18.0 \\
\pm 1.0 \\
\end{array}$ & $\begin{array}{c}25.0 \pm \\
1.0 \\
\end{array}$ & $\begin{array}{l}26.5 \\
\pm 0.0 \\
\end{array}$ & $\begin{array}{r}17.5 \\
\pm 1.5 \\
\end{array}$ & $\begin{array}{c}20.0 \\
\pm 0.0 \\
\end{array}$ & $\begin{array}{r}19.0 \\
\pm 0.0 \\
\end{array}$ & $\begin{array}{l}16.0 \\
\pm 0.0 \\
\end{array}$ & $\begin{array}{r}16.0 \\
\pm 0.0 \\
\end{array}$ & NA & NA & NA & NA & NA & NA & NA \\
\hline $\begin{array}{c}\text { Ps. } \\
\text { aerugi } \\
\text { nosa }\end{array}$ & NA & NA & NA & NA & NA & NA & NA & NA & NA & NA & NA & NA & NA & NA & NA \\
\hline $\begin{array}{l}\text { Staph. } \\
\text { aureus }\end{array}$ & $\begin{array}{l}21.0 \\
\pm 1.0\end{array}$ & $\begin{array}{c}26.0 \pm \\
0.0\end{array}$ & $\begin{array}{c}17.0 \\
\pm 0.0\end{array}$ & $\begin{array}{c}19.0 \\
\pm 2.0\end{array}$ & $\begin{array}{l}16.0 \\
\pm 1.0\end{array}$ & $\begin{array}{c}15.0 \\
\pm 0.0\end{array}$ & $\begin{array}{c}13.0 \pm \\
0.0\end{array}$ & $\begin{array}{r}14.0 \\
\pm 1.0\end{array}$ & NA & NA & NA & NA & NA & NA & NA \\
\hline
\end{tabular}

Key: NA = No Activity, DAE - Aqueous Extract of Dry Ginger, DEE - Ethanol Extract of Dry Ginger, FEE - Ethanol Extract of Fresh Ginger

Table 7. M. I. C. and M. B. C. values of Aqueous and Ethanol Extracts of Dry Ginger and Ethanol Extract of Fresh Ginger

\begin{tabular}{|c|c|c|c|c|c|c|}
\hline \multirow{2}{*}{ Test Bacteria } & \multicolumn{3}{|c|}{ M. I. C $(\mathrm{mg} / \mathrm{ml})$} & \multicolumn{3}{c|}{ M. B. C. (mg/ml) } \\
\cline { 2 - 7 } & DAE & DEE & FEE & DAE & DEE & FEE \\
\hline E. coli & 25.0 & 25.0 & 25.0 & 100.0 & 50 & 100 \\
\hline S. typhi & 25.0 & 25.0 & 25.0 & 50.0 & 100 & 50 \\
\hline Staph. aureus & 50.0 & 25.0 & 25.0 & 50.0 & 50 & 100 \\
\hline
\end{tabular}

Key: DAE - Aqueous Extract of Dry Ginger, DEE - Ethanol Extract of Dry Ginger, FEE - Ethanol Extract of Fresh Ginger

\section{Discussion}

The high incidence of bacterial contamination of ready-to-eat vegetable salad observed in this study can be due to factors such as inability to observe the basic sanitation requirement for processing produce that require no pre-heating before consumption, non availability of water in good quantity for washing and pre-disinfection of the fresh vegetables and fruits during mass production of salad. The number of documented outbreaks of human infections associated with the consumption of raw vegetable has increased in recent years. According to the report by the Centre for Disease Control and Prevention (CDC), the number of produce related outbreaks per year doubled between the period 1973 - 1987, and 1988 -1992, during both periods the aetiological agents were known in more than $50 \%$ of the outbreak (Buck et al., 2003).

The isolation of Salmonella $s p$. particularly the multiple antibiotic resistant ones from three location out of five (5) in this study, is very disturbing particularly as one of the samples was obtained from a known standard fast food centre which is expected to have high level of sanitation and personal hygiene during preparation of the salad. Increasing media coverage has focused on vegetable products as the source of many Salmonella outbreaks (Stoppler, 2011). When vegetables or fruits are the source of an outbreak, it means that these products have been handled unsafely, such as processing or preparation on surfaces that have become contaminated with animal faeces or raw poultry. Another way for vegetables to become contaminated is by an infected food handler (Stoppler, 2011).

Staphylococcus aureus contamination of the vegetable salad sample is also of great importance. Staphylococcus aureus has been reported to remain the most prominent ae- tiology of pyogenic infections and that staphylococcal infection leads to a worsening of some already existing superficial infections (Adegoke and Komolafe, 2009). Multiple antibiotic resistant Staphylococcus aureus isolated from the vegetable salad can be a threat to the health of the consumer. In recent years, many isolates of Staph. aureus have evolved resistance to both synthetic and traditional antimicrobial chemotherapy and their prevalence outside the hospital is of potential epidemiological threat (Daum and Seal, 2001; Kaplan et al., 2005).

Two strains of Pseudomonas aeruginosa were isolated from the vegetable salad samples and they were multiple antibiotic resistance strains. Pseudomonas aeruginosa has become an important cause of infection. It is a frequent cause of nosocomial infections such as pneumonia, urinary tract infections (UTIs), and bacteremia (Aloush et al., 2006). Infections caused by Ps. aeruginosa are often severe and life threatening and are difficult to treat because of the limited susceptibility to antimicrobial agents and the high frequency of an emergence of antibiotic resistance during therapy), thus resulting in severe adverse outcomes (Aloush et al., 2006). Multidrug resistant Ps. aeruginosa infections have been reported to be associated with severe adverse clinical outcomes (Aloush et al., 2006).

From the MARI results, $75 \%$ of the $E$. coli isolates showed multiple antibiotic resistance. Escherichia coli is an important gastrointestinal flora which has been known to be capable of accepting and transferring plasmids and these plasmids can be transferred readily under stress to other species. Therefore, this attribute has made E. coli to be considered as an important reservoir of transferable antibiotic resistance (Aibinu et al., 2007). The selection and spread of resistant organisms in developing countries, which can often be traced to complex socioeconomic and behavioural ante- 
cedents, has contributed to the escalating problem of antibiotic resistance worldwide (Aibinu et al., 2007). The difficulties in the treatment of food and water associated gastrointestinal diseases due to $E$. coli have been reported (Patoli et $a l ., 2010)$. This problem is compounded by the continued emergence of antibiotic resistance to a growing number of antibiotics (Goettscha et al., 2000).

The result of the antibiotic susceptibility test showed that all the bacteria isolates were susceptible to Ofloxacin. The less frequent prescription of Ofloxacin by physicians as well as high cost of the drug which probably restricted its procurement and misuse thereby reducing the emergence of resistant bacteria strains can account for the sensitivity of all the bacterial isolates to the drug. It is also known that Ofloxacin (a quinolone) has the ability to inhibit DNA gyrase in bacteria and so leads to lyses of the bacteria cells (BNF, 2009).

Amoxicillin (a $\beta$-lactam antibiotic) was observed to be the least effective as all the bacteria isolates were resistant to it except an isolate of $E$. coli. This could be connected to the easy hydrolysis of the $\beta$-lactam ring by most bacteria as well as the frequent usage of the drug due to its low cost leading to development of resistance by most bacteria.

Some of the bacteria isolates were resistant to other drugs such as Augmentin, Cotrimoxazole, Gentamicin, Nalidixic acid, Nitrofurantoin and Tetracycline. This observed resistance to these drugs is a probable indication of earlier exposure of the isolate to this drugs which may enhance resistance development.

Multiple antibiotics resistance (MAR) index is a tool that reveals the spread of bacteria resistance in a given population. A MAR index greater than 0.2 , implies that the strains of such bacteria originate from an environment where several antibiotics are used. The MAR indices obtained in this study is a possible indication that a very large proportion of the bacteria isolates have been exposed to several antibiotics. Resistance to antimicrobial agents is an increasing public health threat (NNIS, 2004). It limits therapeutic options and leads to increased mortality and morbidity (Cosgrove and Carmell, 2003). Increase in antibiotic resistance level is now a global problem. Infections with antibiotic resistant bacteria make the therapeutic options for infection treatment, extremely difficult or virtually impossible in some instances (El-Astal, 2004).

The ginger extracts did not show antibacterial activity against Ps. aeruginosa. This result is contrary to that of Azu et al, (2007) who reported that the ginger extracts had antibacterial activity against the organism. The ethanol extract of the fresh and dry ginger showed more antibacterial activity against the test bacteria isolates than the aqueous extract. However, it was observed that the extracts showed more inhibitory/bacteristatic effect than bactericidal effect. This result agreed with the result obtained by Azu et al, (2007) who reported that ginger produced marked inhibitory effect on the test organisms. It has been reported earlier that fresh juice/aqueous extract of ginger did not show any antibacterial activity against this same bacteria isolates (Adeshina et al., 2011). From the result of this study, it is suggested that since ginger is available year round in the produce section of the local market, the fresh or dry ginger can be properly extracted with ethanol, the extract properly evaporated, and added to vegetable salad to inhibit the growth of these bacteria isolates.

\section{Conclusions}

The test vegetable salad samples contained multiple antibiotic resistant bacteria isolates that are potential human pathogens. Ginger fresh and dry ethanol extracts showed inhibitory effect against the resistant bacteria isolates from the vegetable salad samples.

\section{REFERENCES}

[1] Abdul - Raouf, U.M., and Ammar, M.S., 2006, Survival and growth of Eschrichia coli on ready-to-east salad vegetables., Journal of Applied Environmental Microbiology, 59(7), 1999-2006 (s).

[2] Adegoke, A. A., and Komolafe, A. O., 2009, Multi-drug resistant Staphylococcus aureus in clinical cases in Ile-Ife, Southwest Nigeria., International Journal of Medicine and Medical Science, 1(3), $068-072$.

[3] Adeshina, G. O., Jibo, S., Agu, V. E., and Ehinmidu, J. O. 2011, Antibacterial activity of fresh juices of allium cepa and Zingiber officinale against multidrug resistant bacteria., International Journal of Pharma and Bio Sciences, 2(2), 289 294.

[4] Aibinu, I.E., Peters, R.F., Amisu, K.O., Adesida, S.A., Ojo, M.O., and Odugbemi, T., 2007, Multidrug Resistance in E.coli 0157 Strains and the Public Health Implication., Journal of American Sciences, 3(3), 285 - 290.

[5] Aloush, V., Navon-Venezia, S., Seigman-Igra, Y., Cabili, S., and Carmeli, Y., 2006, Multidrug-Resistant Pseu domonas aeruginosa: Risk Factors and Clinical Impact., Antimicrobial Agents and Chemotherapy, 50(1), $43-48$.

[6] Azu, N.C., Onyeagba, R .A., Nworie, O., and Kalu, J., 2007. Antibacterial activity of Allium cepa (Onion) and Zingiber officinale (Ginger) on Staphylococcus aureus and Pseudomonas aeruginosa isolated from high vagina swab., The internet Journal of Tropical Medicine, 3(2).

[7] British National Formulary, British Medical Associ ation. Royal Pharmaceutical Society of Great Britain, 29th Edition, pp. $546,542,241,242,2009$.

[8] Buck, J. W., and Walcott, R. R. 2003, Recent trends in microbiological safety of fruits and vegetables., Plant Health Progress, 10, 1092-1098. (s)

[9] Buck, J.W., Walcott, R. R., Buechat, L.R., 2003, Recent trends in microbiological safety of fruit and vegetables., Online. Plant Health progress doi: 10. 1094/PHP 2003-012101-RV.

[10] Cheesbough, M., Microbiological tests. In District laboratory 
practice in tropical countries., 2nd ed. Cam bridge University Press; pp. 189, 2006.

[11] Clinical and Laboratory Standard Institute, 2008. Perfor mance standard for antimicrobial susceptibility testing. Ap proved standard: CLSI document. M100-S18.

[12] Cosgrove, S. E. and Carmell, Y., 2003, The impact of anti microbial resistance on health and economic outcomes., Clinical and Infectious Disease, 36, 1433 -1437.

[13] Daum, R.S., Seal, J. B., 2001, Evolving antimicrobial chemotherapy for Staphylococcus aureus infections: our backs to the wall., Critical Care Medicine, 29 (4: suppl.), 92-96.

[14] Ehinmidu, J.O., 2003, Antibiotics susceptibility patterns of urine bacterial isolates In Zaria, Nigeria., Tropical Journal of Pharmaceutical Research, 2, 223-228.

[15] El-Astal, Z., 2004, Bacterial pathogens and their antimi crobial susceptibility in Gaza Strip, Palestine., Pakistan Journal of Medical Sciences, 20, 365 - 370 .

[16] Goettscha, W, W. vanPelta, Nagelkerkea, N., Hendrixb M. G. R., Buitingc, A. G. M., and Petitd, P. L., 2000, Increas ing resistance to fluoroquinolones in Escherichia coli from urinary tract infections in the Netherlands., Journal of Anti microbial Chemotherapy, 46, 222 -223.

[17] Kaplan, S.L, Hulten, K. G., Gonzalez, B. E., Hammerman, W. A., Lamberth, L., Versalovic, J., Mason, E O. J., 2005, Treatment of Staphylococcus aureus bacteremia in children., Clinical and Infectious Diseases, 40, 1785-1791.

[18] Larry, R.B., 1995, Pathogenic microorganisms asso- ciated with produce., Journal of Food Protection, 59, 204 - 206 (s).

[19] National Nosocomial Infection Surveillance System. NNIS system report, data summary from Jan. 1992 through June 2004, issued October 2004. American Journal of Infectious Control, 32, $470-485$.

[20] Onaolapo, J. A., 1993, Preliminary study on the anti-microbial activities of Cassia tora and Cassia occidentalis. Glimpses Plant Research, 11, 533 - 536.

[21] Patoli, A. A. B., Bushra, V. M., Patoli, G., 2010, High prevalence of multi-drug resistant Escherichia coli in drink ing water Samples from Hyderabad., Journal of Medical Sciences, 8(1), 1- 23.

[22] Portnoy, B. and Geopfert, J. M., 1996, Outbreak of Bacillus spp food poisoning resulting from contaminate vegetables. Am, J. Epidemol., 102: 589-594 (s).

[23] D. Steven and N. M. D. Ehrlich. (2010). Motion sickness. [Online]. Available: http://www.umm.edu/altmed/articles/motion-sickness-00011 0.htm.

[24] Stoppler, M. C., 2011. Is it Salmonella? [Online]. Available: http://www.medicinenet.com/salmonella/article.htm.

[25] Udo S., Andy. I., Umo, A., and Ekpo, M., 2009, Potential human pathogens (bacteria) and their antibiogram in ready-to-eat salads sold in Calabar, South-South, Nigeria., The Internet Journal of Tropical Medical, 5(2).

[26] Viswanathan, P. and Kaur, R., 2001, Prevalence and growth of pathogens on salad vegetables, fruits and sprouts., International Journal of Hygiene Environmental Health, 203 (3).

[27] Whong, C.M.Z., Brocklehurst, T. F., Lund, B. M., 1987, A note on the microbiology of retail packs of prepared Salad vegetables. Journal of Applied Bacteriology., 63, 409 - 415. 